\title{
PHYSICAL DEVELOPMENT OF SCHOOLGIRLS IN UPPER BURMA
}

\author{
BY \\ C. V. FOLL \\ From the Burma Oil Company (1954) Ltd., Rangoon
}

(RECEIVED FOR PUBLICATION MARCH 17, 1958)

It is still popularly believed that the onset of menstruation occurs earlier in tropical climates than in temperate ones. Ellis (1950) studied puberty in Nigeria and found, in his second series, that the median age of the menarche was 14.4 years. This was significantly later than Wilson and Sutherland's (1949) figure of 13.6 for Oxford schoolgirls, the same authors' (1950) figure of 13.49 for Dorset, Oxford and Essex schoolgirls, and Provis and Ellis's (1955) figure of $13 \cdot 35$ for Edinburgh schoolgirls. Wilson and Sutherland (1950) also recorded some observations from Ceylon, and showed a distinct urban-rural difference in the mean age of the menarche; the respective ages being 12.84 and $14 \cdot 39$ years. Such urban-rural differences were not found in their English series.

In this paper it is hoped to confirm Ellis's Nigerian findings and also to provide some information about schoolgirl growth and development in Burma.

\section{Social Factors, Nutrition and Environment}

During December, 1957, 702 schoolgirls, aged 10 to 18 years, were interviewed in Chauk, a town of some 25,000 inhabitants in Upper Burma. The girls were predominantly Burmese, the remaining few being Chinese, Indian or Anglo-Indian. Chauk is a relatively wealthy town and food is plentiful, the basic diet being vegetable (occasionally meat) curry and rice. Some fish and fresh vegetables would commonly be included in most diets. Malnutrition is rarely seen in the town.

Chauk is about 1,470 miles north of the Equator, and in the hot weather the temperature reaches about $112^{\circ} \mathrm{F}$. There are approximately 24 inches of rain each year. There is no malaria and the 'dry zone' in which it lies is one of the healthiest parts of Burma.

The schoolgirls were asked their age and whether or not they had started menstruating. Unlike many tropical peoples where age estimation is largely guess-work, the Burman has an accurate knowledge of his children's ages for several reasons. It is customary for almost all Burmans to have a horoscope made; this is based on an absolutely accurate time and date of birth. Many important decisions are made only after consulting the horoscope, and propitious days are sought for weddings, going into hospital for operations or deliveries, opening new cinemas and other business undertakings. A Burmese year consists of 12 lunar months, alternately 29 days and 30 days long. During the course of every third year there is an extra month. Each full moon is treated as a Sabbath day and many are times of special celebration.

The schoolgirls' heights and weights were also recorded. Weighing was done with the girls clad in angyis (nylon or cotton blouses) and longyis (type of long, usually cotton, skirt). The total weight of clothes would be less than $2 \mathrm{lb}$. Their height was recorded with the girls barefooted.

\section{Age of Menarche}

From the results obtained, it was possible to calculate graphically by probit analysis the 'median' age of the menarche, that age at which half the girls have started their periods; this was found to be 14.4 years. Table 1 shows a comparison between this figure and those obtained by Ellis (1950) and by Wilson and Sutherland (1950).

TABLE 1

COMPARATIVE AGE OF MENARCHE IN VARIOUS GROUPS

\begin{tabular}{|c|c|c|}
\hline Series & & Median Age of Menarche \\
\hline $\begin{array}{l}\text { Wilson and Sutherland } \\
\text { (England) } \\
\text { Ellis and Provis } \\
\text { (Scotland) }\end{array}$ & $\begin{array}{l}(1949) \ldots \\
(1950) \ldots \\
(1955) \ldots\end{array}$ & $\begin{array}{l}13 \cdot 6 \\
13 \cdot 6 \\
13 \cdot 35\end{array}$ \\
\hline $\begin{array}{l}\text { Ellis } \\
\text { (Nigeria) } \\
\text { Wilson and Sutherland } \\
\text { (Ceylon) } \\
\text { This Series } \\
\text { (Burma) }\end{array}$ & $\begin{array}{l}\text { (1950) } 1 \text { st series } \\
\text { 2nd } \text { Ud } \\
(1950) \text { Urban } \\
\text { Rural } \\
(1957) \ldots\end{array}$ & $\begin{array}{l}14 \cdot 22 \\
14 \cdot 40 \\
12 \cdot 10 \\
14 \cdot 5 \\
14 \cdot 40\end{array}$ \\
\hline
\end{tabular}


From the table it may be seen that the Chauk results confirm Ellis's findings in Nigeria, and also Wilson and Sutherland's rural results in Ceylon.

\section{Height and Weight}

Table 2 shows the mean heights and weights arranged in age groups before and after the menarche.

TABLE 2

NUMBERS, MEAN HEIGHTS AND WEIGHTS OF CHILDREN IN PRESENT SERIES

\begin{tabular}{c|c|c|c|c|c|c|c}
\hline & \multicolumn{3}{|c|}{ Before Menarche } & \multicolumn{2}{c|}{ After Menarche } \\
\cline { 3 - 5 } Age & No. & $\begin{array}{c}\text { Height } \\
\text { (in.) }\end{array}$ & $\begin{array}{c}\text { Weight } \\
\text { (lb.) }\end{array}$ & No. & $\begin{array}{c}\text { Height } \\
\text { (in.) }\end{array}$ & $\begin{array}{c}\text { Weight } \\
\text { (lb.) }\end{array}$ \\
\hline 10 & 72 & 48.37 & 53.85 & & & \\
11 & 91 & 49.97 & 57.22 & $1^{*}$ & 53.00 & 84.00 \\
12 & 85 & 52.48 & 66.09 & $8^{*}$ & 57.56 & 77.88 \\
13 & 58 & 53.65 & 73.26 & 49 & 54.83 & 84.43 \\
14 & 20 & 55.50 & 82.50 & 71 & 55.46 & 88.07 \\
15 & $3^{*}$ & 56.50 & 84.00 & 100 & 55.24 & 91.33 \\
16 & $1^{*}$ & 54.00 & 82.00 & 74 & 55.36 & 93.86 \\
17 & $2^{*}$ & 54.30 & 88.00 & 47 & 54.23 & 93.59 \\
18 & & & & 20 & 54.88 & 90.70 \\
\hline
\end{tabular}

* Numbers too small to be of significance.

It may be seen that there is considerable increase in height from year to year until the age of 14 is reached, after which height remains almost constant. There is a similar increase in weight. The cessation of growth in height at the age of 14 is earlier than in the English series and it appears from these results that growth may take place earlier in children in the tropics. For instance, the average height and weight for a Scottish girl aged $11 \frac{1}{2}$ years (Provis and Ellis, 1955) is $55.7 \mathrm{in}$. and $74.5 \mathrm{lb}$. (nude weight). In this series, for a Burman $11 \frac{1}{2}$ years old, the height was $50 \mathrm{in}$. and weight $57 \mathrm{lb}$., a difference of $5.7 \mathrm{in}$. and $17.5 \mathrm{lb}$. This is considerably less than differences in height and weight of the older children as will be shown later.

Another factor that must be considered is that there is a substantial drop in the heights of the 17-year-old group, i.e. those girls born in 1940-41. These children would have suffered during their infancy from the various privations that were common during the Japanese invasion and occupation. A further series taken in 5 years' time would no doubt throw further light on this. Generally speaking children stay at school until older in Burma than in England.

The height difference between the pre-menarche group aged 13 and 14 is 1.85 in.; this group is largely composed of girls who will start menstruating the following year. This pre-menarchial growth spurt has been reported on by Simmons and Greulich (1943).
Comparison between 13- and 14-year-olds before and after the menarche shows a very slight difference in height but a marked difference in weight. This might be taken to confirm the view of Wilson and Sutherland (1950) that increase in height at this age is unaffected by sexual development, though it could also mean that the pre-menarchial spurt of growth has already occurred by the age of 14 .

\section{Body Build}

The measure used is the height (in inches) divided by the cube root of the weight (in pounds); the means of height and weight for each group were used (Table 3).

TABLE 3

BODY-BUILD (MEAN HEIGHT IN IN DIVIDED BY CUBE ROOT OF MEAN WEIGHT IN LB.)

\begin{tabular}{c|c|c}
\hline \multirow{2}{*}{ Age } & \multicolumn{2}{|c}{ Body-build } \\
\cline { 2 - 3 } & Before Menarche & After Menarche \\
\hline 10 & 12.80 & $*$ \\
11 & 12.96 & $*$ \\
12 & 12.98 & 12.49 \\
13 & 12.82 & 12.47 \\
15 & 12.75 & 12.21 \\
16 & $*$ & 12.18 \\
17 & $*$ & 11.94 \\
18 & & 12.21 \\
\hline
\end{tabular}

* Fewer than 10 measurements, value omitted.

In the pre-menarche group it may be seen that height and weight increase in the same proportions. but the post-menarche group shows that girls become heavier for their height.

This study also shows that the Burmese girl is considerably smaller than her English counterpart. For instance the average weight and height (from

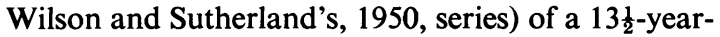
old English girl who has not menstruated is $95 \cdot 8 \mathrm{lb}$. and 60.8 in.; her Burmese contemporary weighs $73.3 \mathrm{lb}$. and is 53.6 in. tall. Similarly the English

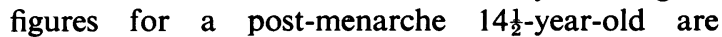
$119.9 \mathrm{lb}$. and 62.5 in. compared with the Burmese $88.1 \mathrm{lb}$. and $55.5 \mathrm{in}$. In other words, the Burmese girl of 13-14 years onwards is some 7 in. shorter and 20-30 lb. lighter than the English girl. That they are smaller from birth has been reported on in an earlier study in Chauk, where the average birth weight for some 200 consecutive single deliveries in 1957 was found to be $6 \mathrm{lb}$. $7 \mathrm{oz}$. for boys and $6 \mathrm{lb} .3 \mathrm{oz}$. for girls (Foll, in press).

The average figures for Scottish newborns (full term by dates, but not all weighing more than $5 \frac{1}{2} \mathrm{lb}$.) were $7 \mathrm{lb} .9 \mathrm{oz}$. (boys) and $7 \mathrm{lb} .5 \mathrm{oz}$. (girls). 


\section{Summary}

A study has been made of 702 predominantly Burmese schoolgirls in Chauk, Upper Burma.

The median age of the menarche is found to be 14.4 years, thus confirming Ellis's (1950) view that the onset of menstruation takes place later in tropical climates and not earlier as is often believed.

The study of height and weight confirms Wilson and Sutherland's (1950) suggestion that in adolescent girls growth is of two superimposed types: physical growth dependent on age and sexual growth dependent on sexual development.

It is suggested that growth starts earlier in the tropics and that little growth in height takes place after the age of 14 .
Early nutritional deprivation may well have an effect on subsequent growth.

The Burmese girl is shown to be lighter and shorter than her English and Scottish contemporary.

I am indebted to Professor R. W. B. Ellis for his advice and helpful criticism in the preparation of this paper; also to the Management of the Burma Oil Co. (1954) Ltd. for facilities granted to me, to the headmasters of the various schools who so willingly co-operated, and especially to Dr. Onmar Khin who interviewed the children.

\section{REFERENCES}

Ellis, R. W. B. (1950). Brit. med. J., 1, 85.

Foll, C. V. (1958). In press. J. Trop. Pediat.

Provis, H. S. and Ellis, R. W. B. (1955). Arch. Dis. Childh., 30, 328. Simmons, K. and Greulich, W. W. (1943). J. Pediat., 22, 518. Wilson, D. C. and Sutherland, I. (1949). Brit. med. J., 2, 130 